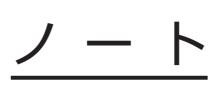

医療薬学

37(5) $305-309$ (2011)

\title{
$\mathrm{P}$-糖タンパク基質のラット消化管吸収に対する 黒酢(国内産玄米酢)の影響
}

\author{
岩尾一生 ${ }^{1,2}$ ，木村なつほ ${ }^{1}$ ，小田雅子 ${ }^{1}$ ，小林道也 ${ }^{1}$, 齊藤浩司*1 \\ 北海道医療大学薬学部薬剤学講座 ${ }^{1}$, 北海道医療大学病院薬片部 ${ }^{2}$
}

\section{Effect of Kurosu(Japanese Unpolished Rice Vinegar) on Absorption of P-glycoprotein Substrates in Rat Small Intestine}

\author{
Kazunari Iwao ${ }^{1,2}$, Natsuho Kimura ${ }^{1}$, Masako Oda ${ }^{1}$, \\ Michiya Kobayashi ${ }^{1}$ and Hiroshi Saitoh ${ }^{* 1}$ \\ Department of Pharmaceutics, Faculty of Pharmaceutical Sciences, \\ Health Sciences University of Hokkaido ${ }^{1}$, \\ Department of Pharmacy, Health Sciences University of Hokkaido Hospital ${ }^{2}$ \\ $\left[\begin{array}{l}\text { Received October 26, } 2010 \\ \text { Accepted February 22, } 2011\end{array}\right]$
}

\begin{abstract}
The objective of this study was to assess possible interaction between kurosu (japanese unpolished rice vinegar) and Pglycoprotein (P-gp), using rhodamine 123 (Rho-123) and glibenclamide (GB) as known P-gp substrates. The absorption of the drugs was investigated using an in situ loop technique. Three $10-\mathrm{cm}$ loops were created in the rat small intestine - in the duodenal, jejunal, and ileal regions. Then, a test solution was introduced into each loop and its disappearance rate after 30 min was determined.

In the presence of kurosu, Rho-123 absorption markedly increased in the 3 regions. Although the lipophilicity of GB was greater than that of tolbutamide (TB), GB absorption was much less than that of TB in the 3 regions, which implied that an efflux transporter restricted GB absorption. However, typical P-gp inhibitors such as verapamil and cyclosporin A slightly increased GB absorption. Also, the enhancing effect of kurosu on GB absorption was limited.

The present results suggest that some components of kurosu are capable of strongly interfering with P-gp function in the intestine and increasing the absorption of P-gp substrates. Our data also imply that an efflux transporter other than P-gp is involved in the low absorption of GB.
\end{abstract}

Key words — kurosu, P-glycoprotein, rhodamine 123, glibenclamide, intestinal absorption, drug interaction

\begin{abstract}
緒言
現在，さまざまな健康食品が普及し，患者が自己判断 で処方薬とともにそれらを服用する例が増加している. 健康食品の中には，薬物の体内動態に影響を及ぼすもの が多数存在する ${ }^{1}$ が，セント・ジョーンズ・ワート等の 一部の健康食品を除いて, その相互作用の機序について は未解明の部分が多い．医薬品と健康食品との相互作用 は，長期にわたり複数の治療薬を服用し続ける慢性疾患 患者において特に留意すべきである。例えば糖尿病患者 においては生涯に渡り厳密な血糖值のコントロールが必 要であり, 健康食品の摂取による直接的な，あるいは糖 尿病治療薬との相互作用などに基づく間接的な血糖值へ
\end{abstract}

の影響は，症状の増悪を招く危険性を孕んでいる。

われわれはこれまで, 北海道医療大学病院の外来糖尿 病患者における治療薬の処方状況ならびに健康食品の使 用実態を調査し，グリベンクラミド(GB)等のスルホニ ル尿素系薬剤(SU郕)を処方される患者が多いこと，また 黑酢(国内産玄米酢)などの健康食品を使用する患者が比 較的多いことを報告した ${ }^{2,3)}$. 一方，年齢が高くて罹病 期間が長いほど，また糖尿病コントロールが悪い患者ほ ど黒酢等の健康食品を利用する頻度が高いことも報告さ れている4).したがって，患者の中にはGB と黒酢を併 用する例のあることも予測される。しかしながら，黒䣷 がイトラコナゾールの吸収を増大させるという報告5)が あるものの，黒酢の薬物相互作用についてはこれまでほ とんど検証されていない. 
最近の研究で, GBの消化管吸収には有機アニオン輸 送ポリペプチド(OATP)や, 分泌トランスポーターであ る $\mathrm{P}-$ 糖タンパク (P-gp)が関与することが報告されてい る, そ). そこで本研究では, P-gp 基質の消化管吸収に対 する黒酢の影響を明らかにするために，代表的基質であ るローダミン 123(Rho-123) とGBの消化管吸収に対する 黒酢の影響について，ラット小腸 in situループ法により 検討を加えた。

\section{方法}

\section{1. 薬物および試薬}

Rho-123はAcros Organics(Morris Plains)から購入した。 GB, トルブタミド(TB), ベラパミル塩酸塩(VER)ならび にシクロスポリン $\mathrm{A}(\mathrm{CsA})$ は, 和光純薬工業株式会社か ら購入した。黑酢は，市販の純玄米黑酢(オリヒロ(株)) を用いた。その他の試薬はすべて市販の特級規格または それに準ずる規格を用いた

\section{2. 試験液の調製}

薬物溶液の調製には, $6 \mathrm{mM}$ D-グルコースを含む夕イ ロード液 $\left(137 \mathrm{mM} \mathrm{NaCl}, 3 \mathrm{mM} \mathrm{KCl}, 2 \mathrm{mM} \mathrm{CaCl}_{2}, 2 \mathrm{mM}\right.$ $\left.\mathrm{MgCl}_{2}, 12 \mathrm{mM} \mathrm{NaHCO}, 0.4 \mathrm{mM} \mathrm{NaH} \mathrm{PO}_{4}\right)$ を使用した. $\mathrm{GB}$ およびTB は水に難溶であることから，あらかじめ エ夕ノールに溶解させて原液を調製し, これを溶解補助 剤として $\beta$-シクロデキストリンを添加したタイロード 液で使用濃度まで希釈し実験に供した。 $\beta$-シクロデキス トリンの濃度は, 医薬品の吸収実験に影響を与えないこ とが確認されている $1 \%$ とした ロード液にて 2 倍または 10 倍に希釈して実験に供した。 使用した黒酢は $\mathrm{pH}$ 約 3.0 と酸性を呈し，また緩衝作用 が強いためにタイロード液を用いて通常の吸収実験条件 である $\mathrm{pH}$ 6 7.4に調整するには相当量の希釈が必要 だったことから，黒酢共存下での吸収実験は $\mathrm{pH}$ を3.5に 調整して行った。

\section{3. in situ ループ法による吸収実験}

実験計画は北海道医療大学動物実験センター管理運営 委員会によって審査・承認され, 動物実験は北海道医療 大学動物実験指針に従って行った。in situループ法によ る吸収実験は, Levine と Pelikan ${ }^{9)}$ おびSaitoh ${ }^{10)}$ の方 法に準拠して行った。 まず体重 240-480 g の Wistar 系雄 性ラット((株)ホクドー)を 15〜18 時間絶食した後, エー テルとペントバルビタールナトリウム $(40 \mathrm{mg} / \mathrm{kg}$, 腹腔 内投与)で麻酔し, 十二指腸部, 空腸部, 回腸部にルー プを作成した。すなわち，胃幽門部 $2 \mathrm{~cm}$ 下から約 $10 \mathrm{~cm}$ の部分を十二指腸ループ，その下に約 $10 \mathrm{~cm}$ の間隔をお き，そこから下方へ約 $10 \mathrm{~cm}$ の部分を空腸ループ，また 回盲部の約 $5 \mathrm{~cm}$ 上から上方へ約 $10 \mathrm{~cm}$ の部分を回腸ルー プとした，各ループ内を生理食塩液で洗浄しながら内容
物を除去した後, ループの両端を結紮しシリンジで試験 液 $1 \mathrm{~mL}$ を注入して直ちに腸管を腹腔内に戻した。な お，腸管内への胆汁の流入を避けるために胆管をあらか じめ結紮した。また全身麻酔による体温低下を防ぐため に，吸収実験中はランプを用いてラットを保温した。試 験液投与 30 分後に各ループを速やかに小腸より単離 し, 生理食塩液中でループ表面の血液を除去した後, ループ内液をメスフラスコ中に回収した。さらにタイ ロード液でループ内を洗浄しながら全量を $10 \mathrm{~mL} に$ た。

また，ループ粘膜への薬物蓄積量を算出するために, 粘膜部分をスライドグラスで擦過した後夕イロード液 (pH 7.4)を加えて氷冷下ホモジナイズし, 全量を $10 \mathrm{~mL}$ とした，得られたループ内液および粘膜ホモジネート各 $200 \mu \mathrm{L}$ にメタノール $200 \mu \mathrm{L}$ を加え, 水冷下にて 10 分放 置後, 遠心分離 $\left(5,350 \times \mathrm{g}, 5^{\circ} \mathrm{C}, 10\right.$ 分)した。得られた 上清中の薬物濃度をHPLCにて測定した。 なお，採取し た試料は定量時までー $30^{\circ} \mathrm{C} に て$ 凍結保存した。

\section{4. 分配係数の測定}

あらかじめオクタノールを飽和させたタイロード液 (pH3.5，6.0または 7.4)を用いて薬物溶液 $(50 \mu \mathrm{M})$ を調製 し，共栓試験管に $3 \mathrm{~mL}$ ずつ分注した。 これにタイロー ド液を飽和させたオクタノールを $3 \mathrm{~mL}$ ずつ添加し, 室 温にて1時間振とうした。振とう終了後，直ちに遠心分 離 $\left(1,150 \times \mathrm{g}, 5^{\circ} \mathrm{C}, 10\right.$ 分 $)$ ，オクタノール層を吸引除去 した後，タイロード液中の残存薬物濃度を HPLCにて測 定した。初期濃度を A，振とう後のタイロード液中濃度 を $\mathrm{A}^{\prime}$ と，次式より $\log$ 分配係数( $\left.\log \mathrm{P}\right)$ を算出した。 $\log \mathrm{P}=\log \left(\mathrm{A}-\mathrm{A}^{\prime}\right) / \mathrm{A}^{\prime}$

\section{HPLC 分析}

HPLC は, SPD-10A VP UV/VIS detector((株)島津製作 所)を備えたLC-10AT VP((株)島津製作所)を使用した。 カ ラムは Cosmosil 5C18-AR( $5 \mu \mathrm{m}, 4.6 \times 150 \mathrm{~mm}$, ナカライテ スク(株))を用いた。移動相として， Rho-123の定量には $0.05 \mathrm{M} \mathrm{KH}_{2} \mathrm{PO}_{4}: \mathrm{CH}_{3} \mathrm{CN}=6 ： 4$ を，GBの定量には $0.05 \mathrm{M}$ $\mathrm{KH}_{2} \mathrm{PO}_{4}: \mathrm{CH}_{3} \mathrm{CN}=1$ : 1を，TBの定量には $0.05 \mathrm{M} \mathrm{KH}_{2} \mathrm{PO}_{4}$ ： $\mathrm{CH}_{3} \mathrm{CN}=7 ：$ 6をそれぞれ用いた。 流速はRho-123で 0.6 $\mathrm{mL} / \mathrm{min}, \mathrm{GB}$ で $1.0 \mathrm{~mL} / \mathrm{min}$, TB で $0.7 \mathrm{~mL} / \mathrm{min}$ とた。 カラム温度は $50^{\circ} \mathrm{C}$ とし, Rho- 123 は $500 \mathrm{~nm}, \mathrm{~GB}$ は $230 \mathrm{~nm}$, TBは226nmでそれぞれ検出した。

\section{6. 統計処理}

結果はすべて平均值 \pm 標準誤差(mean \pm S.E.)で示し た。二群間の有意差検定はStudent's $t$-testにより行っ た。また，多群間検定は一元配置分散分析(One-factor ANOVA)により行い, 有意差が認められた場合に多重比 較検定(デー夕数が等しい場合：Tukey-Kramer test, デー 夕数が異なる場合：Scheffe's F test)を行った. $p<0.05$ を 


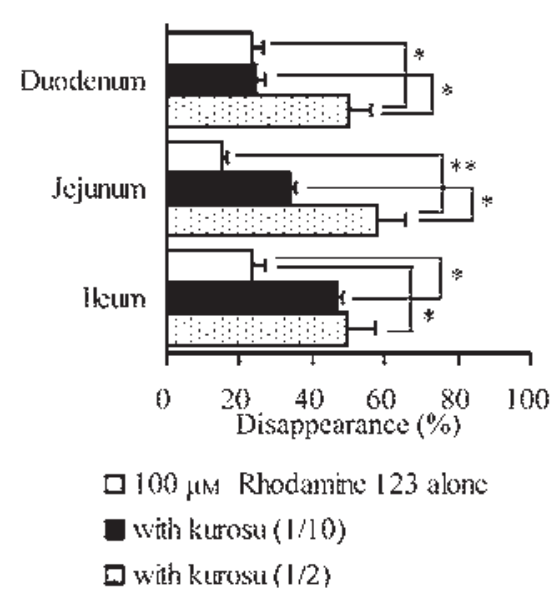

Fig. 1. Effect of Kurosu on the Disappearance of Rhodamine $123(100 \mu \mathrm{M})$ from Rat Intestinal Loops

Medium pH was set at 3.5. Each column represents the mean with S.E. of 3 experiments.

${ }^{*} p<0.05, * p<0.01$, significantly different from rhoda mine 123 alone or rhodamine 123 with kurosu(1/10).

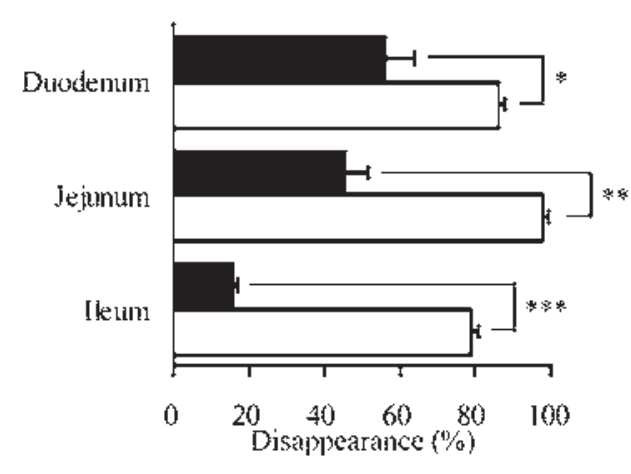

- 50 pra Gibenclamies

$\square 50$ unis Tolbutamide

Fig. 2. Disappearance of Glibenclamide and Tolbutamide from Rat Intestinal Loops

Initial drug concentration was $50 \mu \mathrm{M}$. Medium $\mathrm{pH}$ was set at 6.5. Each column represents the mean with S.E. of 4 experiments. ${ }^{*} p<0.05,{ }^{* *} p<0.01$, $* * * p<0.001$, significantly different from tolbutamide.

Table 1. Log Partition Coefficients of Glibenclamide and Tolbutamide between n-Octanol and Tyrode's Solution

\begin{tabular}{lcccc}
\hline & $\mathrm{p} K_{\text {; }}$ & \multicolumn{4}{c}{$\log \mathrm{P}$} \\
\cline { 3 - 5 } & & $\mathrm{pH} 3.5$ & $\mathrm{pH} 6.5$ & $\mathrm{pH} 7.4$ \\
\hline Glibenclamide & 6.8 & $1.21 \pm 0.02$ & $1.19 \pm 0.02$ & $1.12 \pm 0.0 \mathrm{~J}$ \\
Jobutamide & 5.43 & $\mathrm{n.d.}$ & $0.04 \pm 0.01$ & $-0.37=0.00$ \\
\hline
\end{tabular}

The pla of Tyrode's solution was 6.5

Fach value represents dhe mean \pm S.F. of 3 sxperiments. n.d., net determined.

もって有意差ありとした.

\section{結果}

\section{Rho-123の吸収に対する黒酢の影響}

2 倍希釈の黒酢共存下で, 代表的 P-gp 基質であ るRho-123のラット小腸ループからの消失率は十二指腸 部，空腸部，回腸部でそれぞれ約 50\%，58\%，50\%であ り，単独投与時に比べ各部位で有意に増大した(Fig. 1).

一方，10倍希䣋の黑酢共存下では Rho-123の消失率はそ れぞれ約 25\%，34\%，47\% となり，回腸部で有意な増大 がみられた。

\section{2. グリベンクラミドおよびトルブタミドの吸収挙動}

GB が P-gp の基質になることは報告されている7もの の，その吸収特性についてはほとんど報告されていな い、そこで，GBの吸収に対する黒酢の影響を検討する のに先だって, 同じ SU 剽である $\mathrm{TB} と \mathrm{~GB}$ のラット小腸 ループからの吸収性を比較した(Fig. 2).この吸収実験は
pH 6.5 の条件下で行ったが, TB の消失率は十二指腸部 で約 86\%, 空腸部で約 98\%, 回腸部で約 79\%であり, 小腸各部位でその吸収性はかなり良好であった。これに 対し, GB の消失率は十二指腸部で約56\%, 空腸部で約 $46 \%$, 回腸部で約 16\%であり, 各部位で GB の吸収性は TBに比べ低い值を示した，その傾向は特に回腸部にお いて顕著であった。

$\mathrm{pH} 3.5 ， 6.5$ 拉よび 7.4 に㧍ける GB およびTB の $\log \mathrm{P}$ はいずれも 1 以上であった(Table 1). 一方, TB の $\log \mathrm{P}$

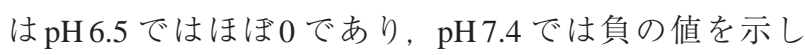
た. $\mathrm{pH} 3.5$ ではオクタノール層へのTBの分配が極めて 大きく, $\log \mathrm{P}$ 值は算出できなかった(Table 1). これらの

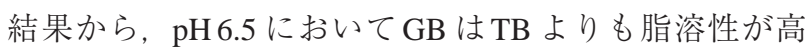
いにもかかわらず，TBよりも吸収されにくいことが明 らかになった。

投与 30 分後に挍ける TB の粘膜蓄積率は小腸各部位に おいて $4 \%$ 以下であったのに対し，GBでは十二指腸部 で約 $12 \%$, 空腸部で約 17\%, 回腸部で約 $8 \%$ の蓄積がみ られ，TBに比べ消失率は有意に低かったにもかかわら 
ず，粘膜蓄積は各部位で TBよりも有意に大きい結果と なった。

脂溶性が高いにもかかわらず吸収性が低いという GB の吸収特性がP-gp によって引き起こされているか否か を確認するために，P-gpの代表的阻害剤であるVER と CsA を共存させ，GBの吸収に対する影響について検討 した。その結果，VERおよびCsA共存下でGBの消失に 一部有意な増加が認められた(Fig. 3).

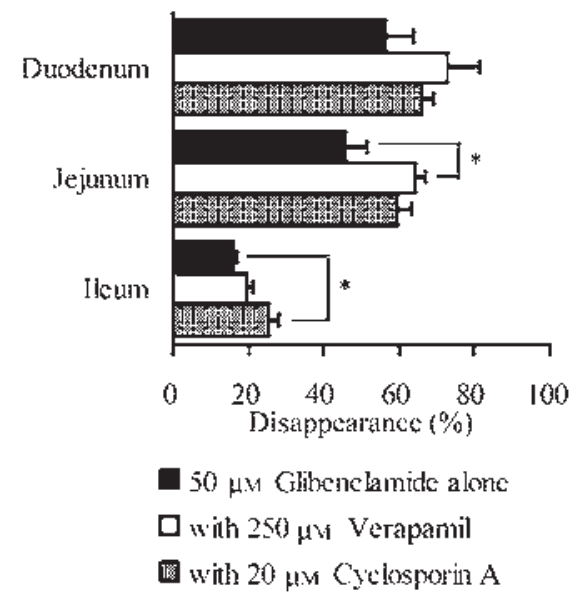

Fig. 3. Effect of Verapamil and Cyclosporin A on the Disappearance of Glibenclamide from Rat Intestinal Loops Initial concentration of glibenclamide was $50 \mu \mathrm{M}$. The concentration of verapamil and cyclosporin A was $250 \mu \mathrm{M}$ and $20 \mu \mathrm{M}$, respectively. Mediumu $\mathrm{pH}$ was set at 6.5. Each column represents the mean with S.E. of 4 experiments. ${ }^{*} p<0.05$, significantly different from glibenclamide alone.

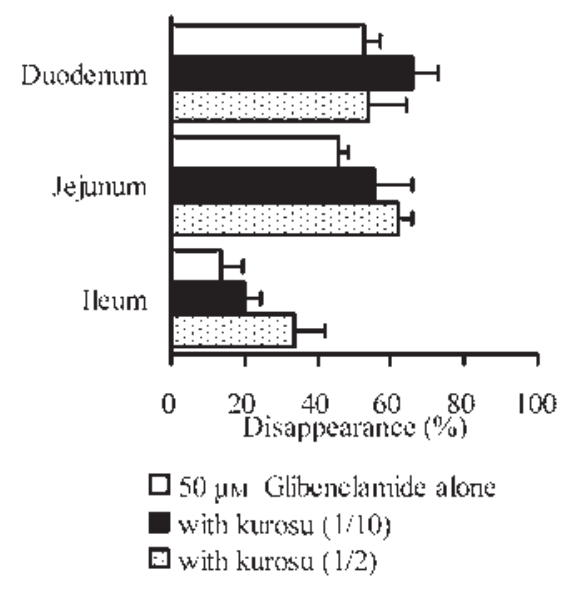

Fig. 4. Effect of Kurosu on the Disappearance of Glibenclamide $(50 \mu \mathrm{M})$ from Rat Intestinal Loops Medium pH was set at 3.5. Each column represents the mean with S.E. of 3-4 experiments.

\section{3. グリベンクラミドの吸収に対する黒酢の影響}

2 倍希釈の黒酢を共存させた場合，十二指腸部，空腸 部, 回腸部における GB の消失率はそれぞれ約 54\%, 62\%，34\%であり，一方，10倍希釈の黒酢共存下での消 失率はそれぞれ約 66\%，55\%，20\% であった(Fig. 4).い ずれの場合にも有意差は認められなかったものの, 小腸 各部位におけるGBの消失は黒酢共存下で増大する傾向 を示した。

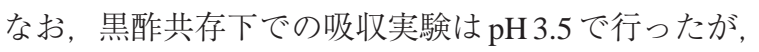
この条件下における GB の消失率は小腸各部位において pH 6.5の場合とほぼ同程度であった。このことから, pH 3.5 の条件下で粘膜障害等により小腸透過性が変化する 可能性は低いと考えられた。

\section{考察}

今回, ラット小腸 in situ ループ法での検討により, P-gp 基質モデルとして汎用される Rho-123の吸収が黒酢 共存下で増大するという知見が得られた(Fig. 1)。これま でにも種々の食品成分が P-gp と相互作用を示すことが 報告されてきた ${ }^{11,12)}$ が, 今回の結果は本研究に用いた黒 酢中にP-gp を強く阻害する成分が含まれる可能性を示 唆した，黒酢には，原産地の異なるものあるいは製法が 異なるもの等, さまざまな製品が市販され，それにより 含有成分が異なることも予想される。したがって，本研 究で得られた黒酢とP-gp との相互作用をさらに検証す るために, 今後複数の黒酢製品を用いて, この結果の再 現性を確認する必要がある。

また，黒酢にはクエン酸等，種々の有機酸が含まれる が，これら有機酸の中には小腸上皮細胞間隙を修飾して 薬物の透過を促進する作用を示すものがある ${ }^{13)}$. した がって，黒䣷中の有機酸によって Rho-123の吸収が促進 された可能性も残されており, 今後分泌トランスポー ターの基質とならない薬物を用いて黒酢の影響を検討す る必要があると判断される。

GB はP-gpの基質となることが報告されている7゙が, 臨床では P-gp 誘導剤であるリファンピシンやP-gp 阻害 剤であるべラパミル, クラリスロマイシンの併用によっ てGBの血中濃度が減少する, あるいは増加するという 知見 ${ }^{14-16)}$ や，GB を服用中のII型糖尿病患者がクラリス ロマイシンを併用したところ重篤な低血糖症状に陥った 事例 ${ }^{17)}$ が報告されており，これらはいずれも P-gpを介す る薬物相互作用とみなされている。しかしながら今回の 検討では, 小腸ループ内にVER P CsA を共存させて も，各部位における GBの消失率の増大は一部に有意差 はみられたもののそれほど顕著ではなく(Fig. 3), P-gpの 強い関与を示唆する結果は得られなかった。これを反映 して，Rho-123の吸収を大きく増大させた黒酢の効果も 限定的であった(Fig. 4). Gedeon ${ }^{18)}$ は GB の胎盤透過制 御に乳がん耐性タンパク(BCRP)や多剂耐性関連タンパ 
ク (MRP)が関与していると報告している。 BCRPや MRP は小腸粘膜にも発現していることから，ラット小腸でみ られたGBの低吸収性には P-gp 以外の分泌トランスポー ターが密接に関与している可能性も考えられる. GBの 低吸収性に関わる要因については，今後さらに詳細に検 討を進める必要がある。

今回の検討では，脂溶性がそれ程高くないにもかかわ らずTBがラット小腸各部位において良好に吸収される ことが示された(Fig. 2). TBの消化管吸収については,

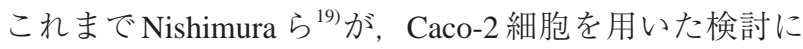
おいて TB の吸収方向の透過にトランスポーターが介在 することを報告している。したがって今回の知見は，ラ ット小腸においてTBがこうしたトランスポーターを介 して良好に吸収された可能性を反映するものと考えられ た.

結論として，黒酢の含有成分の中に小腸 P-gp を阻害 するものが存在することが示唆された。 したがって，

P-gp の基質となる医薬品では黒酢との併用により吸収 が増大し，治療効果が影響を受ける可能性がある。 小腸 のシトクロム P450(CYP)3A4への影響も含め, 黒酢と薬 物との相互作用についてさらなる検討が必要と考えられ る.

\section{引用文献}

1) R.T. Harris, G.R. Jang, S. Tsunoda, Dietary effects on drug metabolism and transport, Clin. Pharmacokinet., 42, 10711088(2003).

2) 岩尾一生，小林道也，及川孝司，中駄優作，藤崎博子，室 谷光治，伊藤昭英，辻昌宏，井出肇，遠藤泰，関川涁，齊 藤浩司, 糖尿病外来患者における健康食品の使用実態調 査(第 1 報) 一健康食品に対する患者意識と利用状況 - , 医療薬学, 34, 112-117(2008).

3) 岩尾一生, 小林道也, 及川孝司, 中駄優作, 藤崎博子, 室 谷光治，伊藤昭英，辻昌宏，井出肇，遠藤泰，関川彬，齊 藤浩司, 糖尿病外来患者に扔ける健康食品の使用実態調 査(第 2 報) 一糖尿病用薬と健康食品との関係一, 医療 薬学, 34, 118-123(2008).

4) 黄恵涁, 木村博典, 宮下賜一郎, 堀江一郎, 長良子, 亀田 智子，糖尿病患者に扔ける民間療法の実態調査，国立病 院機構長崎医療センター医学雑誌, 10, 19-24(2007).

5) 小熊毅, 田端宏道, 相原顕作, 松本正孝, 鍵岡均, 長野 正信，福井基成，イトラコナゾールカプセルの吸収にお ける黒酢の効果についての検討，感染症学雑誌，83, 369-374(2009).

6) H. Satoh, F. Yamashita, M. Tsujimoto, H. Murakami, N. Koyabu, H. Ohtani, Y. Sawada, Citrus juices inhibit the function of human organic anion-transporting polypeptide OATP-B, Drug Metab. Dispos., 33, 518-523(2005).

7) P.E. Golstein, A. Boom, J. van Geffel, P. Jacobs, B. Masereel, R. Beauwens, P-glycoprotein inhibition by glibenclamide and related compounds, Pflügers Arch., 437, 652-660(1999).

8) M. Oda, H. Saitoh, M. Kobayashi, B.J. Aungst, $\beta$-Cyclodextrin as a suitable solubilizing agent for in situ absorption study of poorly water-soluble drugs, Int. J. Pharm., 280, 95-102(2004).

9) R.R. Levin, E.W. Pelikan, The influence of experimental procedures and dose on the intestinal absorption of anionium compound, benzomethamine, J. Pharmacol. Exp. Ther., 131, 319-327(1961).

10) H. Saitoh, M. Hatakeyama, O. Eguchi, M. Oda, M. Takada, Involvement of intestinal P-glycoprotein in the restricted absorption of methylprednisolone from rat small intestine, $J$. Pharm. Sci., 87, 73-75(1998).

11) W.V. de Castro, S. Mertens-Talcott, H. Derendorf, V. Butteeweck, Grapefluit juice-drug interactions: Grapefruit juice and its components inhibit P-glycoprotein(ABCB1) mediated transport of talinolol in Caco-2 cells, J. Pharm. Sci., 96, 2808-2817(2007).

12) H.H. Yoo, M. Lee, H.J. Chung, S.K. Lee, D.H. Kim, Effects of diosmin, a flavonoid glycoside in citrus fruits, on P-glycoprotein-mediated drug efflux in human intestinal Caco2 cells, J. Agric. Food Chem., 55, 7620-7625(2007).

13) M. Hayashi, M. Tomita, Physiological mechanism for enhancement of paracellular drug transport, J. Controlled Rel., 62, 141-148(1999).

14) M. Niemi, J.T. Backman, M. Neuvonnen, P.J. Neuvonnen, K.T. Kivistö, Effects of rifampin on the pharmacokinetics and pharmacodynamics of glyburide and glipizide, Clin. Pharmacol. Ther., 69, 400-406(2001).

15) C.G. Semple, C. Omile, K.D. Buchanan, G.H. Beastall, K.R. Paterson, Effect of oral verapamil on glibenclamide stimulated nsulin secretion, Br. J. Clin. Pharmacol., 22, 187-190(1986).

16) J.J. Lilja, M. Niemi, H. Fredrikson, P.J. Neuvonen, Effects of clarithromycin and grapefruit juice on the pharmacokinetics of glibenclamide, Br. J. Clin. Pharmacol., 63, 732-740(2007).

17) R. Bussing, A. Gende, Severe hypoglycemia from clarithromycin-sulfonylurea drug interaction, Diabetes Care, 25, 1659-1661(2002).

18) C. Gedeon, J. Behravan, G. Koren, M. Piquette-Miller, Transport of glyburide by placental ABC transporters: Implications in fetal drug exposure, Placenta, 27, 10961102(2006).

19) N. Nishimura, K. Naora, T. Uemura, H. Hirano, K. Iwamoto, Transepithelial permeation of tolbutamide across the human intestinal cell line, Caco-2, Drug Metab. Pharmacokin., 19, 48-54(2004). 